Review Article:

\title{
Safety Profile of Using Ciprofloxacin in Paediatrics: A Systematic Review and Meta-Analysis
}

\author{
Baraneh Masoumi $^{1}$ (D) , Gohar Eslami ${ }^{2}$ (D), Reza Alizadeh-Navaei ${ }^{3}$ (D) Pritish Mondal $^{4}$ (D) Mohammad Sadegh Rezai $^{1^{*}}$ (D) \\ 1. Paediatric Infectious Diseases Research Centre, Mazandaran University of Medical Sciences, Sari, Iran. \\ 2. Department of Clinical Pharmacy, Faculty of Pharmacy, Cardiovascular Research Center, Mazandaran University of Medical Sciences, Sari, Iran \\ 3. Gastrointestinal Cancer Research Center, Mazandaran University of Medical Sciences, Sari, Iran. \\ 4. Department of Paediatrics, Division of Pulmonary, Penn State College of Medicine, Hershey, Pennsylvania, USA.
}

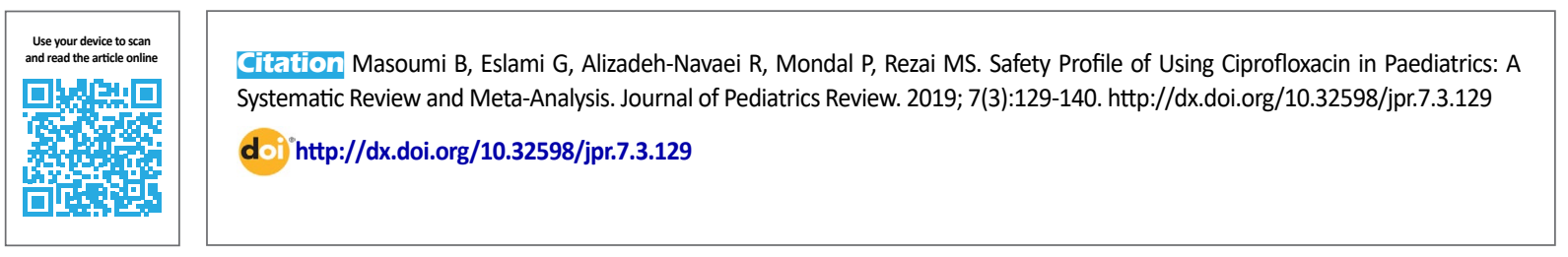

(c) (i) (5)

Article info:

Received: 28 August 2018

First Revision: 16 October 2018

Accepted: 17 October 2018

Published: 01 July 2019
Keywords:

Pediatrics,

Ciprofloxacin, Safety profile, Arthropathy, Fluoroquinolones

\section{A BSTRACT}

Context: The use of ciprofloxacin is contraindicated in children due to safety concerns. Animal studies have revealed that ciprofloxacin can be associated with arthropathy (joint toxicity) in juvenile animals; however, this potential side effect has not been proven in children. Many clinicians still prescribe ciprofloxacin when there is no suitable alternative. In many developing countries, access to the newer generation of antibiotics is either limited or expensive. Therefore, ciprofloxacin is an available and cost-effective alternative that can save lives when necessary.

Objective: This study aimed to systemically review the published studies about the safety profile of using ciprofloxacin in children.

Data Sources: All relevant studies published from 1990 to 2018 in the Cochrane library, Trip database, ScienceDirect, PubMed, and Google Scholar were collected.

Study Selection: We have only considered clinical trials, which included the following keywords: "ciprofloxacin", "children under 18 years", and "arthropathy".

Data Extraction: The collected data were analyzed by Comprehensive Meta-Analysis software (CMA.2). We used random or fixed-effect methods based on the heterogeneity of the results. The heterogeneity was checked by $\mathrm{l}^{2}$ index and tau-squared. The publication bias was evaluated by the Begg's test.

Results: The obtained data indicated no increased risk of arthropathy after ciprofloxacin use in children on a short-term basis, in comparison to placebo or other antibiotics.

Conclusions: Ciprofloxacin is potentially a safe alternative to be used in children under 18 years old when there is no better alternative.

* Corresponding Author:

Mohammad Sadegh Rezai, MD.

Address: Paediatric Infectious Diseases Research Centre, Mazandaran University of Medical Sciences, Sari, Iran.

Tel: +98 (11) 33342334

E-mail: rezai@mazums.ac.ir 


\section{Context}

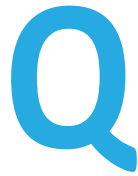

uinolones have been used for many years for treatment of various infectious diseases. Nalidixic acid is the first quinolone that was discovered in 1962 (1). However, due to its limitations, such as toxicity issues, the narrow spectrum of antibacterial activity and low serum bioavailability, it is no longer used in practice $(1,2)$. The fluorination of quinolones resulted in the production of fluoroquinolones. Ciprofloxacin is a second-generation fluoroquinolone, which was discovered in 1987 (1). Ciprofloxacin and other second-generation fluoroquinolones have superior properties compared to nalidixic acid, such as the broad-spectrum bactericidal activity, and appropriate tissue penetration (2). Considering the above-mentioned properties, these antibiotics are more suitable to be used in practice $(1,3)$.

\subsection{Mechanism of action}

Although the antimicrobial resistance is increasing, many bacteria are still sensitive to fluoroquinolones (4). Based on the evidence, ciprofloxacin is the safest and most effective antibiotic in children compared to other fluoroquinolones $(3,5)$. It is effective in a wide range of Gram-positive and Gram-negative pathogens and acts by interfering with DNA functioning and inhibiting DNA gyrase and topoisomerase IV in bacteria. These enzymes are essential for DNA replication, transcription, repair, and recombination $(5,6)$.

Fluoroquinolones have many favorable properties in the treatment of bacterial infections in adults and children $(2,4,5)$. Despite their effectiveness, the use of these antibiotics in growing children were limited due to the debatable safety concerns over the risk of joint toxicity and other adverse side effects (2). In vitro study of juvenile animals of different species, such as dogs, mice, rats, and rabbits, have illustrated that the use of ciprofloxacin and other quinolones can cause arthropathy in weight-bearing joints $(2,3)$. No evidence has proved the definite joint injury induced by ciprofloxacin in children (5). Since adverse effects are inevitable, fluoroquinolones like ciprofloxacin are recommended when other options are not available or effective (5).

\subsection{Pharmacokinetics}

The pharmacological data available on the use of ciprofloxacin to treat hospitalized pediatric patients are scarce. The literature review suggests that the half-life of ciprofloxacin is significantly longer in infants (under 1 year old) than toddlers ( 1 to 5 years old) (3). However, there is a very slight difference in maximum serum concentration levels $(3,7)$. Therefore, it is important to consider the age of the child at prescription. Most research on ciprofloxacin pharmacology has been performed on children with Cystic Fibrosis (CF).

Aradottir et al. (1999) found the Mean \pm SD scores of peak serum concentration and peak time following oral administration as $3.7 \pm 1.4 \mathrm{mg} / \mathrm{L}$ and $2.5 \pm 1.8$ hours, respectively. The same records after intravenous administration were $5.0 \pm 1.5 \mathrm{mg} / \mathrm{L}$ and $1.0 \pm 0.3 \mathrm{~h}$ (7). The mean oral bioavailability of ciprofloxacin was obtained $76 \%$ in the same study. Younger patients (about 68\%) absorb ciprofloxacin less compared to older patients (95\%). Due to the higher clearance of this drug in adults, smaller doses are recommended in children. Ciprofloxacin is eliminated through renal and hepatic pathways (2).

\subsection{Indications}

Some guidelines approve the use of fluoroquinolones in pediatrics when the first line of treatment is not effective and no alternative is available $(8,9)$. Normally, the fluoroquinolone of choice is ciprofloxacin, due to its higher safety profile in comparison with other fluoroquinolones. Ciprofloxacin is prescribed in children with serious infections when its benefit outweighs the risks (3). The potential indications in pediatrics that several European and American guidelines agreed on include respiratory infections with Pseudomonas $(P)$ aeruginosa in cystic fibrosis, multidrug-resistant infections, particularly in immunocompromised patients and those under chemotherapy, multidrug-resistant Shigella and Salmonella infections, and complicated urinary tract infections $(5,8,9)$.

The mentioned infections are the main indications of ciprofloxacin in pediatrics. Furthermore, in the model list of essential medicines for children by the World Health Organization (WHO) (2010), ciprofloxacin (250 $\mathrm{mg}$ tablets) is only indicated for Shigella infection treatment in children aged 1 to 17 years, but not neonates $(5,6)$. While there are newer generations of fluoroquinolones available in the first world countries and developing countries, the shortage of these antibiotics has remained an issue (10). However, ciprofloxacin is the most cost-effective, cost-benefit, and available antibiotic in fluoroquinolones that can be used in practice in such countries $(3,10)$. Furthermore, upon discharging the patients on intravenous antibiotics from the hospital, the regimen must change to an oral preparation 
when appropriate, which is more convenient for the patients and their parents (11).

\section{Objective}

Ciprofloxacin is an appropriate oral antibiotic applicable in many serious infections when there is no available alternative. There is no recent systemic review available to confirm the safety of this antibiotic in children. The present review aimed to collect evidence from clinical trials to evaluate the safety of using ciprofloxacin, focusing on arthropathy in children on a short-term basis ( 2 to 3 weeks).

\section{Data Sources}

The reviewed databases were Cochrane library, Trip database, ScienceDirect, PubMed, and Google Scholar as well as hand searching.

\section{Study Selection}

We have only considered clinical trials and the applied keywords that have been used were "ciprofloxacin", "fluoroquinolones", "pediatrics", "arthropathy", and "children under 18 years".

\section{Data Extraction}

A pediatrician and a pharmacist screened the collected data. We only included the full text English clinical trials and those focusing on pediatrics. We have considered ciprofloxacin treatment, as well as prophylaxis for different conditions. The factors that were included in this study were patients' age, underlying conditions, administration route, treatment duration, and potential side effects, with a special focus on arthropathy or cartilage toxicity. The studies that only involved adults were excluded from our research. Inclusion criteria consisted of the studies with

6501 studies concering ciprofloxacin and other fluoeoquinolones

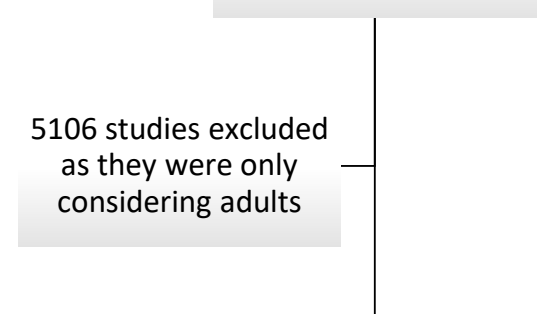

1395 studies

(paediatrics)

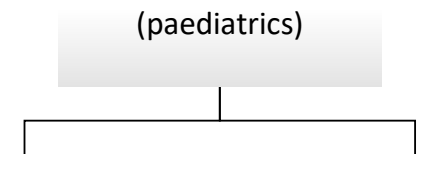

109 studies (clinical trials)
1286 studies excluded as they were no clinical trial 
the study patients aged $\geq 18$ years and children with underlying conditions such as CF and malignancies.

\subsection{Statistical analysis}

The obtained data were analyzed by Comprehensive Meta-Analysis software (CMA.2). We used random or fixed-effect methods base on the heterogeneity of the results. Heterogeneity was checked by $\mathrm{I}^{2}$ index and Tausquared. The standard continuity correction of 0.5 was applied to zero events. Publication bias was evaluated by the Begg's test.

\section{Results}

We identified a total of 109 studies (Figure 1). From those, 26 studies investigated the safety of ciprofloxacin use in children and most of them were randomized clinical trials and observational studies. Appendix 1 presents the details of these 26 studies. We collected data from clinical trials published from 1990 to 2018. In total, there were 16155 pediatric study patients who were exposed to ciprofloxacin as a treatment for a range of indications. Among those, there were 82 reports of musculoskeletal adverse reactions.

Some studies suggest the risk of arthropathy associated with the use of ciprofloxacin equal to less than $1 \%$ (about $0.82 \%$ ), and some stated that the odds could be as high as $3.3 \%(3,5)$. Appendix 1 presents that the ciprofloxacin use in neonates (under 1 month old) is less likely to cause arthropathy; however, there exists a possibility of under-diagnosis in this age group. The obtained data suggest that the youngest age of the child's ciprofloxacin prescription was 3 days old $(12,13)$ (Tables 1 and 2).

\section{Discussion}

This systematic and meta-analysis review was conducted to evaluate the safety of using ciprofloxacin in children. We have pooled together and analyzed all the relevant articles, for drawing a conclusion in this regard. The studied reports in this review were clinical trials on the safety of ciprofloxacin and its suspected adverse events, especially arthropathy in children. Ciprofloxacin is not the first line recommended antibiotic in children (except for limited indications), based on joint toxicity reported by juvenile animal studies $(1,3)$. Ciprofloxacin is widely used in practice despite being contraindicated in this age category (3). We have investigated the arthropathy risk associated with ciprofloxacin and the effect of underlying conditions, treatment duration, age, and its dosage.

Fifteen out of 26 studies compared ciprofloxacin use to a control group; with 5 using a placebo in the con-

Table 1. The summary of musculoskeletal complications in children with cystic fibrosis

\begin{tabular}{|c|c|c|c|c|c|}
\hline Results & $\begin{array}{l}\text { No. of Musculoskeletal } \\
\text { Complications }\end{array}$ & $\begin{array}{l}\text { Drug Dose, } \\
\mathrm{mg} / \mathrm{kg} / \text { day }\end{array}$ & $\begin{array}{l}\text { Treatment } \\
\text { Duration }\end{array}$ & Patients' Age & $\begin{array}{c}\text { Study No. } \\
\text { (Appendix 1, } \\
\text { Table 1) }\end{array}$ \\
\hline $\begin{array}{l}\text { Treatment discontinued in } \\
3 \text { patients ( } 2 \text { of } 3 \text { had CF) }\end{array}$ & 10 & $4-53$ & 15 days & $<19$ years old & 3 \\
\hline $\begin{array}{c}1 \text { mild pain of knee } \\
\text { (continued) } \\
1 \text { severe knee and ankle } \\
\text { joints pain (discontinued) }\end{array}$ & Arthropathy $n=2$ & $10-20$ & - & 5 days- 14 years & 6 \\
\hline $\begin{array}{l}\text { All patients with } \\
\text { arthropathy had CF }\end{array}$ & Arthropathy $n=8$ & $3.1-93.8$ & $1-30$ days & 3 days-17 years & 7 \\
\hline $\begin{array}{l}\text { Ciprofloxacin is } \\
\text { well-tolerated in CF }\end{array}$ & 0 & $25-30$ & 32 months & $7-17$ years & 9 \\
\hline $\begin{array}{c}\text { No arthropathy during or } \\
2 \text { weeks after the end of } \\
\text { therapy }\end{array}$ & 0 & $10-60$ & - & $<18$ years & 12 \\
\hline $\begin{array}{l}\text { Arthropathy not related to } \\
\text { dose or duration }\end{array}$ & 0 & $21.25 \pm 6.35$ & $\begin{array}{l}21 \text { days (except } 2 \\
\text { cases that } \\
\text { received long- } \\
\text { term Cipro) }\end{array}$ & $2-18$ years & 13 \\
\hline $\begin{array}{c}\text { No statistical differences } \\
\text { between placebo and } \\
\text { ciprofloxacin treated } \\
\text { groups }\end{array}$ & 0 & $15-20$ & 18 months & $1-12$ years & 15 \\
\hline
\end{tabular}


Table 2. The summary of musculoskeletal events in children with cancer

\begin{tabular}{|c|c|c|c|c|c|}
\hline Outcome & $\begin{array}{l}\text { No. of Musculoskeletal } \\
\text { Events }\end{array}$ & Dose (mg/kg/day) & $\begin{array}{l}\text { Treatment } \\
\text { Duration }\end{array}$ & Patients' Age & $\begin{array}{l}\text { Study No. } \\
\text { (Appendix 1, } \\
\text { Table 1) }\end{array}$ \\
\hline $\begin{array}{l}1 \text { discontinuation due to } \\
\text { maculopapular rash }\end{array}$ & 0 & 10 & 18 days & $\begin{array}{l}3 \text { months-18 } \\
\text { years }\end{array}$ & 2 \\
\hline $\begin{array}{l}\text { Treatment discontinued in } \\
3 \text { patients ( } 2 \text { of } 3 \text { had CF) }\end{array}$ & 10 & $4-53$ & 15 days & $<19$ years & 3 \\
\hline- & 0 & 25 & 9 days & $0-13$ years & 5 \\
\hline $\begin{array}{c}\text { Ciprofloxacin use as } \\
\text { prophylaxis in patients } \\
\text { with Acute lymphoblastic } \\
\text { leukemia }\end{array}$ & 0 & $\begin{array}{l}\text { Depending on body } \\
\text { weight }\end{array}$ & Long-term & $0-15$ years & 20 \\
\hline No arthropathy & 0 & $\begin{array}{c}20 \text { (to maximum of } \\
500 \mathrm{mg} \text { ) }\end{array}$ & No fixed duration & $1-21$ years & 21 \\
\hline $\begin{array}{l}\text { Treating patients with } \\
\text { oral ciprofloxacin or IV } \\
\text { ceftriaxone for fever and } \\
\text { neutropenia is effective } \\
\text { and safe }\end{array}$ & 0 & $8-25$ & No fixed duration & $3-20$ years & 23 \\
\hline
\end{tabular}

trol group. The rest were compared to other antibiotics (Figure 2). As shown in Figure 2, the decrease in arthropathy after treatment with fluoroquinolones compared to other antibiotic or placebo was 0.67 (95\% $\mathrm{Cl}$ : 0.5-0.89), which was statistically significant. The heterogeneity $\mathrm{I}^{2}$ index and tau-squared were $32.2 \%$ and 0.36 , respectively. Egger's test suggested no publication bias in the studies ( $P=0.729)$.
In conclusion, arthropathy has occurred either less frequently or equally in three studies with ciprofloxacin use, compared to placebo or other antibiotics (Figure 2). Laoprasopwattana et al. (2013) compared the use of ciprofloxacin to other antibiotics. They illustrated that arthropathy occurrence was the same in the ciprofloxacintreated and control (placebo) groups (14).

Study number 17 reported that the incidence of joint dysfunction associated with the use of ciprofloxacin and

\section{MetaAnalysis}

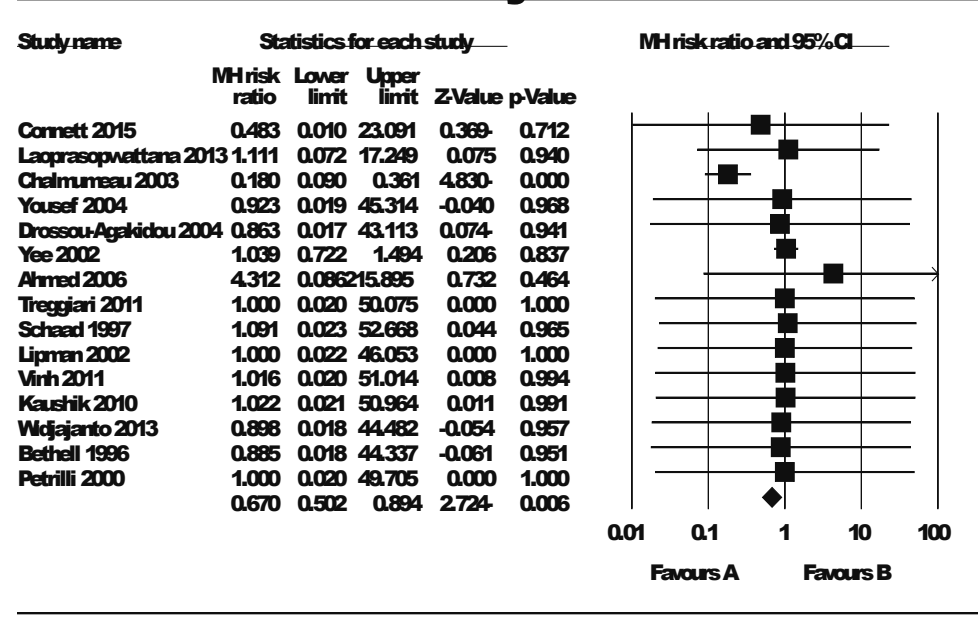


ofloxacin was $0.82 \%$ (13 of 1539), compared to $0.78 \%$ for azithromycin (118 of 15073) (15). However, azithromycin usually has no adverse effects on joint, tendon or cartilage; thus, the incidence of arthropathy could be related to the underlying conditions in the studied children rather than the antibiotics use $(15,16)$.

Underlying conditions, therefore, can be an important factor in the occurrence of arthropathy in children. Studies number 7, 14 and 26, listed in Appendix 1 revealed a higher number of children with joint-related side effects after ciprofloxacin exposure. However, all those children had CF and two studies have reported that arthropathy occurred in $7 \%$ to $8 \%$ of pediatric patients with CF even without ciprofloxacin exposure $(17,18)$. Consequently, having $\mathrm{CF}$ as an underlying condition can increase the risk of arthralgia development in children (17-19). Ciprofloxacin is often used in children with CF compared to other diseases. Therefore, a higher incidence of ciprofloxacin-related arthropathy is observed in this group of patients.

The follow-up time for investigating the arthropathy occurrence or any other joint toxicity after ciprofloxacin exposure in these studies ranged from two weeks to three years $(2,19)$. Arthralgia occurred in about $50 \%$ of the musculoskeletal complications and ranged from the mild pain of joints to inflammation and severe pain in patients. In total, only 9 children out of 82 who developed musculoskeletal problems discontinued their treatment with ciprofloxacin. All cases of arthralgia were reversible and patients remained asymptomatic on long-term follow-up $(2,8,12,20,21)$.

We have also investigated the potential link between the treatment duration and arthropathy risk. In 7 studies ciprofloxacin has been used on a short-term ( 2 to 3 weeks) basis and the reported joint toxicity was either very small or none, which could indicate the possible effect of treatment duration on the risk of developing arthropathy $(2,14,15,21-23)$. In most studies, the shortterm use of ciprofloxacin has not been associated with arthropathy even after a long-term follow-up of the patients $(15,16,21,24-31)$.

Only two studies have observed arthropathy occurrence in short-term ciprofloxacin usage. However, the incidence rate was either similar (study No. 2) or smaller (study No. 3) compared to the control groups. This could indicate that ciprofloxacin exposure was not the only factor causing arthropathy in those patients $(2,3)$. Contrary to these findings, which recognized the treatment duration as a risk factor in arthropathy occurrence, the finding of only one study was not compatible with the others. Faghihi (2017) study suggests that the risk of joint toxicity or arthropathy is not related to the dose or duration of treatment (32). However, this study had some limitations, including small sample size, no control group, and missing the effect of underlying conditions on arthropathy occurrence in pediatrics.

Furthermore, we have studied the potential relationship between the children's age and incidence of arthropathy. Of total 16155 children who studied in our dataset, 82 children developed joint problems after or during the ciprofloxacin treatment. The majority of these children were $\geq 6$ years old. Only 7 of 82 affected children were under 6 years old, which indicates a much lower percentage compared to the older ones (8.5\% vs. $91.5 \%)(8,12,15,20)$. In addition, the use of ciprofloxacin in neonates up to one-year-old has not been associated with an increase in arthropathy incidence (16, 19). Therefore, ciprofloxacin use may be safe in younger ages, especially neonates.

In general, ciprofloxacin was administrated either orally or intravenously. The doses have been calculated according to the patient' weight and ranged from 3.1 to $93.8 \mathrm{mg} / \mathrm{kg} /$ day and were normally prescribed in two divided doses. We failed to find any relationship between the ciprofloxacin dose and arthropathy occurrence. This finding is similar to the review by Adefurin et al. (2011) where they could not confirm this relationship (1). We have considered ciprofloxacin treatment as well as prophylaxis use in this study. According to the collected data, the prophylactic use of ciprofloxacin has not been associated with an increased risk of arthropathy $(9,14)$. There were no major limitations associated with this study. However, we excluded some articles in this study from Embase due to the access limitations.

\section{Conclusions}

Our systemic review identified a relatively low and reversible risk of arthropathy associated with ciprofloxacin use in children compared to other fluoroquinolones. This adverse event is less likely to occur in short-term use and the incidence could also be related to other factors such as patients' underlying conditions and other medications used. Therefore, we suggest that when needed, this antibiotic can be prescribed safely in most children without the risk of joint toxicity. We suggest that future research is performed on patients with underlying conditions, especially those with CF to understand the effect of these conditions among children, with respect to arthropathy occurrence. 


\section{Ethical Considerations}

\section{Compliance with ethical guidelines}

All ethical principles were considered in this article. The participants were informed about the purpose of the research and its implementation stages; they were also assured about the confidentiality of their information; Moreover, They were allowed to leave the study whenever they wish, and if desired, the results of the research would be available to them.

\section{Funding}

This research did not receive any specific grant from funding agencies in the public, commercial, or not-forprofit sectors.

\section{Authors contributions}

Conceptualization, Methodology, investigation and analysis: All authors; Writing-original draft: Baraneh Masoumi; and Supervision: Mohammad Sadegh Rezai, Gohar Eslami.

\section{Conflict of interest}

The authors declared no conflict of interest.

\section{References}

1. Adefurin A, Sammons H, Jacqz-Aigrain E, Choonara I. Ciprofloxacin safety in pediatrics: A systematic review. Archives of Disease in Childhood. 2011; 96(9):874-80. [DOI:10.1136/ adc.2010.208843] [PMID] [PMCID]

2. Meesters K, Mauel R, Dhont E, Walle JV, De Bruyne P. Systemic fluoroquinolone prescriptions for hospitalized children in Belgium, results of a multicenter retrospective drug utilization study. BMC Infectious Diseases. 2018; 18(1):89. [DOI:10.1186/s12879-018-2994-z] [PMID] [PMCID]

3. Gendrel D, Moulin F. Fluoroquinolones in pediatrics. Pediatric Drugs. 2001; 3(5):365-77. [DOI:10.2165/00128072200103050-00005] [PMID]

4. Bradley JS, Jackson MA, Committee on Infectious Diseases, American Academy of Pediatrics. The use of systemic and topical fluoroquinolones. Pediatrics. 2011; 128(4):e103445. [DOI:10.1542/peds.2011-1496] [PMID]

5. World Health Organization. Second meeting of the subcommittee of the expert committee on the selection and use of essential medicines. Geneva: World Health Organization; 2018.
6. Bourgeois T, Delezoide AL, Zhao W, Guimiot F, Adle-Biassette $H$, Durand $E$, et al. Safety study of Ciprofloxacin in newborn mice. Regulatory Toxicology and Pharmacology. 2016 74:161-9. [DOI:10.1016/j.yrtph.2015.11.002] [PMID]

7. Aradottir E, Yogev R. The use of fluoroquinolones in paediatrics- A reassessment. Seminars in Pediatric Infectious Diseases 1999; 10(1):31-7. [DOI:10.1016/S10451870(99)80007-7]

8. Jung C, Shamdasani S. Antimicrobial agents and related therapy. In: Kimberlin DW, Brady MT, Jackson MA, Long SS, editors. Red Book: Report of the Committee on Infectious Diseases. Itasca, Illinois: American Academy of Pediatrics; 2009.

9. Newland JG, Hersh AL. Purpose and design of antimicrobial stewardship programs in pediatrics. The Pediatric Infectious Disease Journal. 2010; 29(9):862-3. [DOI:10.1097/ INF.0b013e3181ef2507] [PMID]

10. Orenstein DM, Pattishall EN, Noyes BE, Kurland G, Hartigan ER, Yu VL. Safety of ciprofloxacin in children with cystic fibrosis. Clinical Pediatrics. 1993; 32(8):504-6. [DOI:10.1177 /000992289303200811] [PMID]

11. Connett GJ, Pike KC, Legg JP, Cathie K, Dewar A, Foote $\mathrm{K}$, et al. Ciprofloxacin during upper respiratory tract infections to reduce Pseudomonas aeruginosa infection in pediatric cystic fibrosis: A pilot study. Therapeutic Advances in Respiratory Disease. 2015; 9(6):272-80. [DOI:10.1177/1753465815601571] [PMID]

12. Drossou-Agakidou V, Roilides E, Papakyriakidou-Koliouska P, Agakidis C, Nikolaides N, Sarafidis K, et al. Use of ciprofloxacin in neonatal sepsis: Lack of adverse effects up to one year. The Pediatric Infectious Disease Journal. 2004 23(4):346-9. [DOI:10.1097/00006454-200404000-00014] [PMID]

13. Yang ZT, Zahar JR, Méchaï F, Postaire $M$, Blanot $S$, Balfagon-Viel $\mathrm{S}$, et al. Current ciprofloxacin usage in children hospitalized in a referral hospital in Paris. BMC Infectious Diseases. 2013; 13(1):245-8. [DOI:10.1186/1471-2334-13245] [PMID] [PMCID]

14. Laoprasopwattana K, Khwanna T, Suwankeeree $P$, Sujjanunt T, Tunyapanit $\mathrm{W}$, Chelae $\mathrm{S}$. Ciprofloxacin reduces occurrence of fever in children with acute leukemia who develop neutropenia during chemotherapy. The Pediatric Infectious Disease Journal. 2013; 32(3):e94-8. [PMID]

15. Lipman J, Gous A, Mathivha L, Tshukutsoane S, Scribante $\mathrm{J}$, Hon $\mathrm{H}$, et al. Ciprofloxacin pharmacokinetic profiles in pediatric sepsis: How much ciprofloxacin is enough. Intensive Care Medicine. 2002; 28(4):493-500. [DOI:10.1007/ s00134-002-1212-y] [PMID]

16. Treggiari $M$, Retsch-Bogart $G$, Mayer-Hamblett $N$, Khan U, Kronmal R, Ramsey B, et al. Comparative efficacy and safety of four randomized regimens to treat early Pseudomonas aeruginosa infection in children with cystic fibrosis. Archives of Pediatrics and Adolescent Medicine. 2011; 
165(9):847-56. [DOI:10.1001/archpediatrics.2011.136] [PMID] [PMCID]

17. Black A, Redmond AO, Steen HJ, Oborska IT. Tolerance and safety of ciprofloxacin in pediatric patients. Journal of Antimicrobial Chemotherapy. 1990; 26(suppl. F):25-9. [DOI:10.1093/jac/26.suppl_F.25] [PMID]

18. Schaad UB, Sander E, Wedgwood J, Schaffner T. Morphologic studies for skeletal toxicity after prolonged ciprofloxacin therapy in two juvenile cystic fibrosis patients. The Pediatric Infectious Disease Journal. 1992; 11(12):1047-9. [DOI:10.1097/00006454-199211120-00011] [PMID]

19. Ahmed AN, Khan NZ, Saha SK, Chowdhury MA, Muslima H, Law $\mathrm{P}$, et al. Ciprofloxacin treatment in preterm neonates in Bangladesh: Lack of effects on growth and development. The Pediatric Infectious Disease Journal. 2006; 25(12):113741. [DOI:10.1097/01.inf.0000245105.99934.5f] [PMID]

20. Yee CL, Duffy C, Gerbino PG, Stryker S, Noel GJ. Tendon or joint disorders in children after treatment with fluoroquinolones or azithromycin. The Pediatric Infectious Disease Journal. 2002; 21(6):525-9. [DOI:10.1097/00006454200206000-00009] [PMID]

21. Schaad UB. Use of quinolones in pediatrics. European Journal of Clinical Microbiology and Infectious Diseases. 1991; 10(4):355-60. [DOI:10.1007/BF01967011] [PMID]

22. Chalumeau M, Tonnelier $S$, d'Athis $P$, Tréluyer JM, Gendrel $D$, Bréart $G$, et al. Fluoroquinolone safety in pediatric patients: A prospective, multicenter, comparative cohort study in France. Pediatrics. 2003; 111(6):e714-9. [DOI:10.1542/peds.111.6.e714] [PMID]

23. Yousef AA, Fryer CJ, Chedid FD, Abbas AA, Felimban SK, Khattab TM. A pilot study of prophylactic ciprofloxacin during delayed intensification in children with acute lymphoblastic leukemia. Pediatric Blood \& Cancer. 2004; 43(6):637-43. [DOI:10.1002/pbc.20065] [PMID]

24. Singh UK, Sinha RK, Prasad B, Chakrabarti B, Sharma SK. Ciprofloxacin in children: Is arthropathy a limitation. The Indian Journal of Pediatrics. 2000; 67(5):386-7. [DOI:10.1007/ BF02820695] [PMID]

25. Vinh H, Anh VT, Anh ND, Campbell Jl, Hoang NV, Nga TV, et al. A multi-center randomized trial to assess the efficacy of gatifloxacin versus ciprofloxacin for the treatment of shigellosis in Vietnamese children. PLoS Neglected Tropical Diseases. 2011; 5(8):e1264. [DOI:10.1371/journal. pntd.0001264] [PMID] [PMCID]

26. Kaushik JS, Gupta P, Faridi MM, Das S. Single dose azithromycin versus ciprofloxacin for cholera in children: A randomized controlled trial. Indian Pediatrics. 2010; 47(4):30915. [DOI:10.1007/s13312-010-0059-5] [PMID]

27. Widjajanto PH, Sumadiono S, Cloos J, Purwanto I, Sutaryo S, Veerman AJ. Randomized double blind trial of ciprofloxacin prophylaxis during induction treatment in childhood acute lymphoblastic leukemia in the WK-ALL protocol in Indone- sia. Journal of Blood Medicine. 2013; 4:1-9. [DOI:10.2147/ JBM.S33906] [PMID] [PMCID]

28. Aquino VM, Herrera L, Sandler ES, Buchanan GR. Feasibility of oral ciprofloxacin for the outpatient management of febrile neutropenia in selected children with cancer. Cancer. 2000; 88(7):1710-4. [DOI:10.1002/(SICI)10970142(20000401)88:73.0.CO;2-1]

29. Bethell DB, Hien TT, Phi LT, Day NP, Vinh H, Duong NM, et al. Effects on growth of single short courses of fluoroquinolones. Archives of Disease in Childhood. 1996; 74(1):44-6. [DOI:10.1136/adc.74.1.44] [PMID] [PMCID]

30. Krcmery Jr V, Filka J, Uher J, Kurak H, Sagat T, Tuharsky J, et al. Ciprofloxacin in treatment of nosocomial meningitis in neonates and in infants: Report of 12 Cases and. Diagnostic Microbiology and Infectious Disease. 1999; 35(1):75-80. [DOI:10.1016/S0732-8893(99)00052-8]

31. Karande S, Kshirsagar NA. Ciprofloxacin use: Acute arthropathy and long-term follow up. Indian Pediatrics. 1996; 33(11):910-6. [PMID]

32. Faghihi T, Tekmehdash LY, Radfar M, Gholami K. Ciprofloxacin use in hospitalized children: Approved or off-label. Journal of Research in Pharmacy Practice. 2017; 6(4):193-8. [DOI:10.4103/jrpp.JRPP_17_27] [PMID] [PMCID] 
Appendix 1. The summary of the clinical trial studies that reported the safety of ciprofloxacin in pediatrics

\begin{tabular}{|c|c|c|c|c|c|c|c|c|c|c|c|}
\hline$\dot{0}$ & 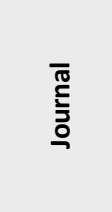 & 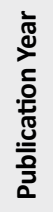 & 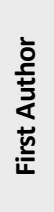 & 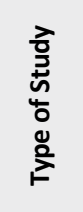 & $\begin{array}{l}\bar{\Xi} \\
\alpha^{\prime}\end{array}$ & $\begin{array}{l}\dot{0} \\
\dot{z} \\
\dot{0}\end{array}$ & 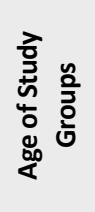 & 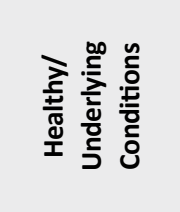 & 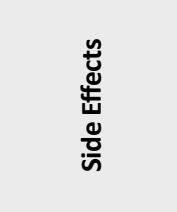 & 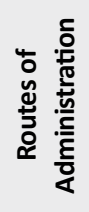 & 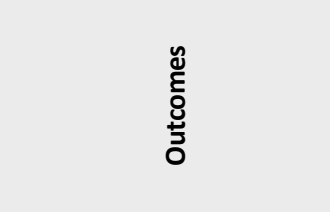 \\
\hline$\rightarrow$ & 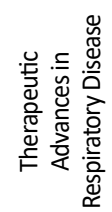 & 㟋 & 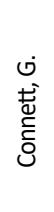 & $\underset{\propto}{\longleftarrow}$ & $\begin{array}{l}\text { no } \\
\text { i } \\
\text { v }\end{array}$ & $\vec{\gamma}$ & 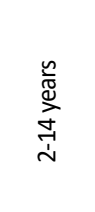 & U & $\mathrm{N} / \mathrm{A}$ & 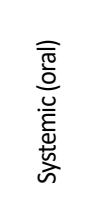 & $\begin{array}{l}\text { Recommendation of use of } \\
\text { ciprofloxacin for } 2 \text { weeks as a } \\
\text { second-line treatment } \\
\text { Concern over the emergence of } \\
\text { resistant by increasing the use } \\
\text { of ciprofloxacin in children }\end{array}$ \\
\hline$\sim$ & 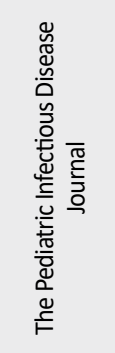 & $\stackrel{m}{\stackrel{n}{N}}$ & 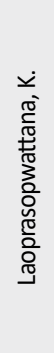 & ঢ્ & $\begin{array}{l}n \\
\text { II } \\
\text { II }\end{array}$ & นn & 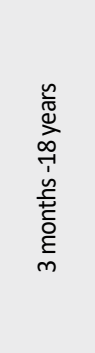 & 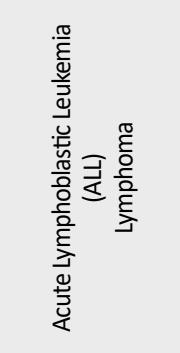 & $\begin{array}{l}\text { Maculopapu- } \\
\text { lar rash in } 1 \\
\text { patient (discon- } \\
\text { tinuation) } \\
\text { Abdominal } \\
\text { pain (2 vs. 5) } \\
\text { Arthralgia/ } \\
\text { arthritis (1 vs.1) }\end{array}$ & 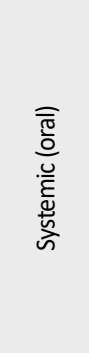 & $\begin{array}{l}\text { Significantly lower (23\%) } \\
\text { development of fever in } \\
\text { patients receiving ciprofloxacin } \\
\text { in comparison to placebo users } \\
\text { during the induction phase of } \\
\text { chemotherapy } \\
\text { Median treatment duration } \\
\text { of } 18 \text { days, which could be a } \\
\text { possible reason for the lower } \\
\text { occurrence of arthropathy in } \\
\text { patients }\end{array}$ \\
\hline$m$ & 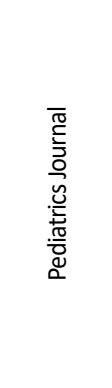 & ర్లి & 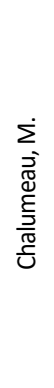 & 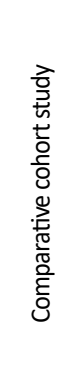 & 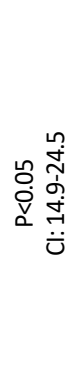 & $\tilde{\tilde{N}}$ & 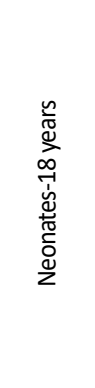 & 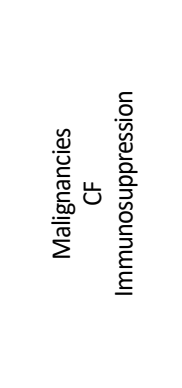 & $\begin{array}{l}\text { GI }(n=15) \\
\text { Muscu- } \\
\text { loskeletal } \\
\text { system }(n=10): \\
\text { arthralgia of } \\
\text { large joints or } \\
\text { myalgia-No } \\
\text { observation of } \\
\text { tendinopathy } \\
\text { Skin }(n=7) \\
\text { Kidney }(n=5) \\
\text { CNS }(n=3)\end{array}$ & 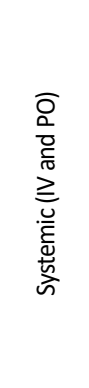 & $\begin{array}{l}\text { Higher incidence of musculo- } \\
\text { skeletal events compared to } \\
\text { adults } \\
\text { These events appeared within } 2 \\
\text { weeks after the initiation of FQ, } \\
\text { mainly observed as large joint } \\
\text { arthralgia of knees, shoulders, } \\
\text { and wrists. } \\
\text { Much higher events of } \\
\text { musculoskeletal events with } \\
\text { pefloxacin }(18.2 \%) \text { compared to } \\
\text { ciprofloxacin }(3.3 \%)\end{array}$ \\
\hline$\sigma$ & 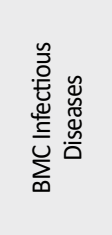 & $\stackrel{\infty}{\check{N}^{2}}$ & 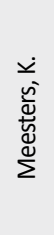 & 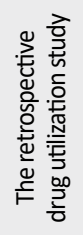 & 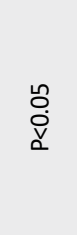 & ర్ల & 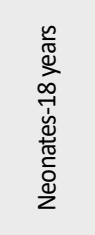 & 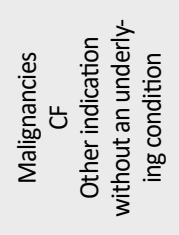 & $\mathrm{N} / \mathrm{A}$ & 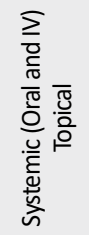 & $\begin{array}{l}\text { Most FQ use for the treatment } \\
\text { of CNS infection ( } 24.8 \%) \text { - off- } \\
\text { label use } \\
\text { Then, prophylaxis of febrile } \\
\text { neutropenia, RI, pneumonia } \\
\text { and UTI }\end{array}$ \\
\hline in & 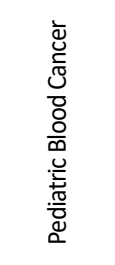 & ర్రి & 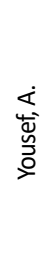 & $\begin{array}{l}\vec{y} \\
\frac{\vec{z}}{4} \\
\frac{0}{2}\end{array}$ & 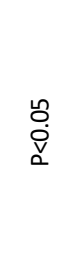 & 8 & $\begin{array}{c}\frac{n}{\pi} \\
\stackrel{\Perp}{\pi} \\
m \\
0 \\
0\end{array}$ & 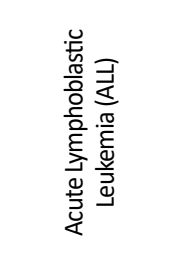 & $\begin{array}{l}\text { No bone or } \\
\text { joint side } \\
\text { effects were } \\
\text { observed in } \\
\text { the test and } \\
\text { control groups }\end{array}$ & 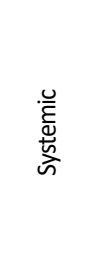 & $\begin{array}{c}\text { Reduction of hospitalization } \\
\text { (decreased to } 58 \% \text { ) } \\
\text { The use of prophylactic } \\
\text { ciprofloxacin in children with } \\
\text { ALL may reduce the incidence } \\
\text { of bacteremia and associated } \\
\text { hospitalization. } \\
\text { Risk of antibiotic resistance }\end{array}$ \\
\hline 0 & 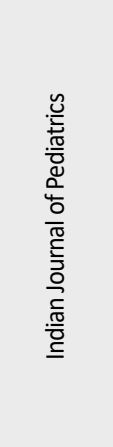 & ষ্ণ & $\begin{array}{l}\stackrel{\dot{0}}{J} \\
\dot{\overline{0}} \\
\text { in } \\
\text { in }\end{array}$ & 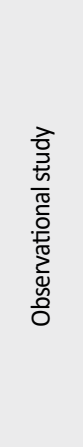 & . & $\stackrel{\text { 구 }}{ }$ & 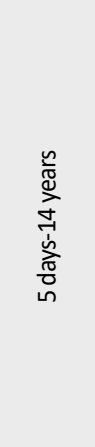 & 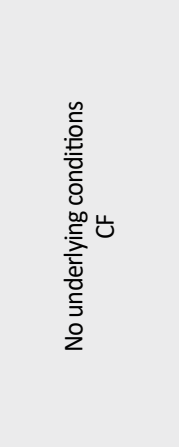 & $\begin{array}{c}\text { Arthropathy } \\
(0.9 \%)\end{array}$ & 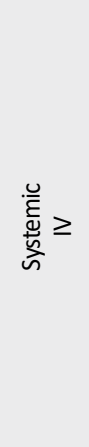 & $\begin{array}{l}\text { Arthropathy only occurred in } \\
\text { two patients (0.09\%), both re- } \\
\text { solved after the discontinuation } \\
\text { of treatment with ciprofloxacin, } \\
\text { X-ray and MRI showed no } \\
\text { abnormality during treatment } \\
\text { and at } 6 \text { months follow-up. } \\
\text { Ciprofloxacin is safe, cheap and } \\
\text { a useful alternative antibiotic } \\
\text { in children, thus, this study sug- } \\
\text { gests the use of it when there } \\
\text { is a case of multidrug-resistant } \\
\text { infection or when the organism } \\
\text { is sensitive to ciprofloxacin. }\end{array}$ \\
\hline
\end{tabular}




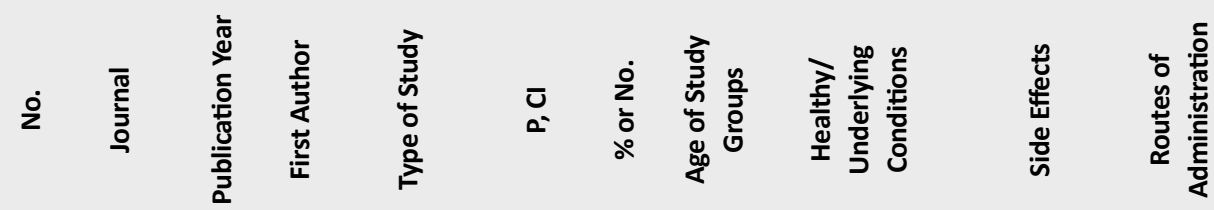

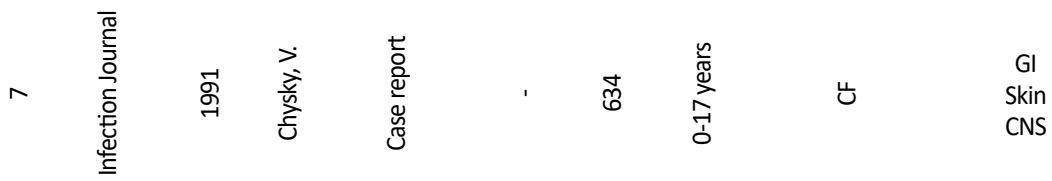
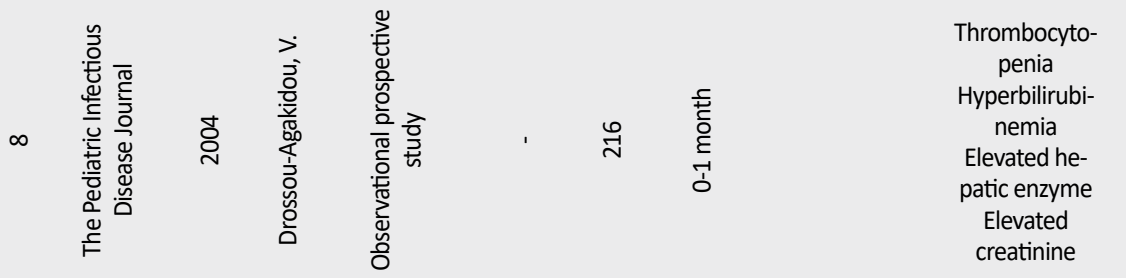

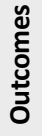

A total of 8 reports of arthralgia (1.3\%). All of them were female and suffering from CF.

All joints complain were

transient and reversible upon discontinuation.

Slight higher incidence of arthralgia in children compared to adults. This can be related to underlying conditions.

No clinical evidence of arthropathy was observed at either the initial hospitalization or follow up.

No potential effect on growth

even though height maybe

totally independent of cartilage damage.

A similar growth rate in both control and test groups.

During the two-week treat-

A slight

increase of serum creatinine concentration

A small

increase

in alkaline

phosphatase

concentration. ment with ciprofloxacin, no arthropathy episode has been observed.

Overall, $7 \%$ to $8 \%$ of CF patients develop arthropathy without exposure to ciprofloxacin.

This study was based on a short course of Ciprofloxacin, use in CF and long-term safety cannot be justified.

This study suggests that the incidence of joint toxicity is

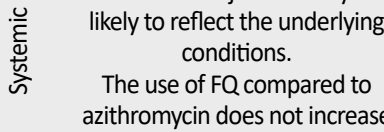

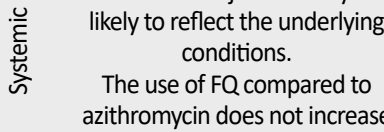

N/A the joint toxicity incidence.

No differences were observed in the development of children in the ciprofloxacin group compared to the control group in terms of first walking, and other aspects of motor, language or cognitive development. No evidence of acute or subclinical joint toxicity was observed in the neonates who were treated with ciprofloxacin.

No notice of any bone/joint when ciprofloxacin was used in short term. 


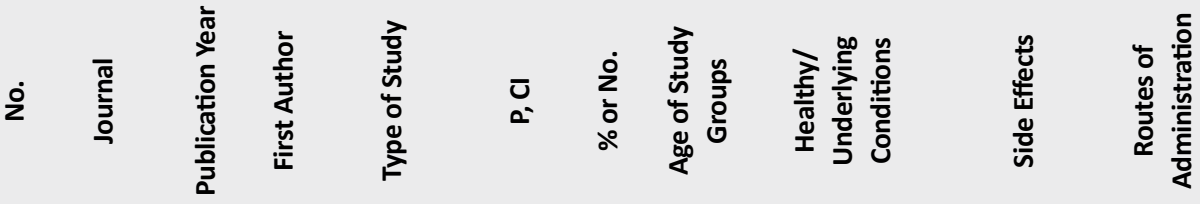

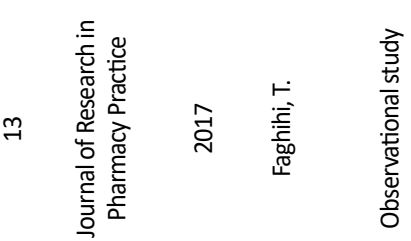

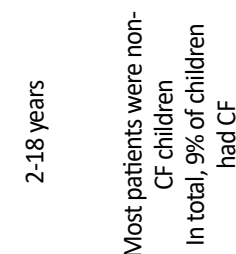

No other side effect has been discussed in this study.

$\approx$

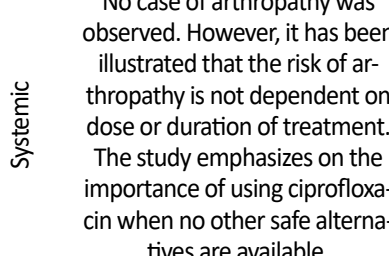
tives are available.

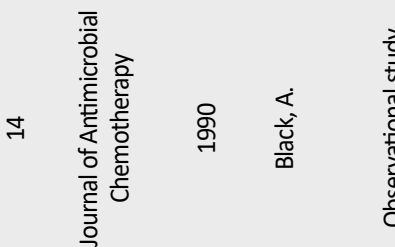

จิ

GI

Arthralgia

Skin

Renal

Thrombophle-

bitis

Dizziness

Hallucinations

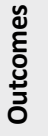

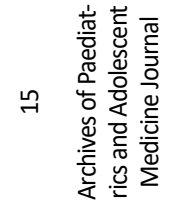

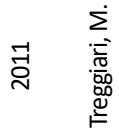

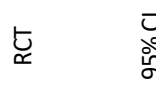

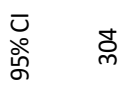

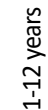

嵵

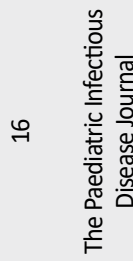

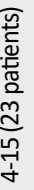
Abdominal

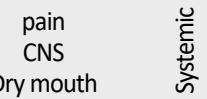
The study concludes that the use of ciprofloxacin in CF pa- tients can improve the clinical, bacteriologic and pulmonary functions.
Ciprofloxacin is well tolerated and no sign of ciprofloxacin- related skeletal toxicity has been observed.

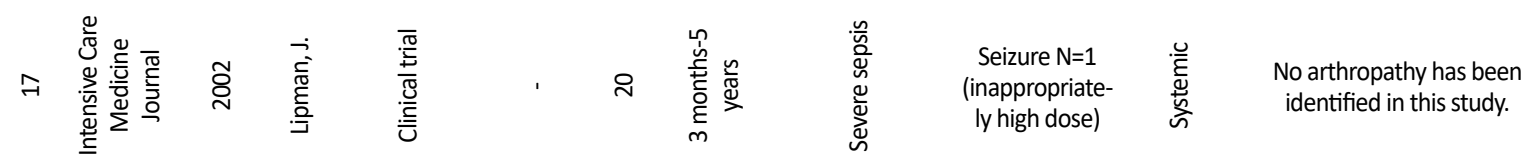

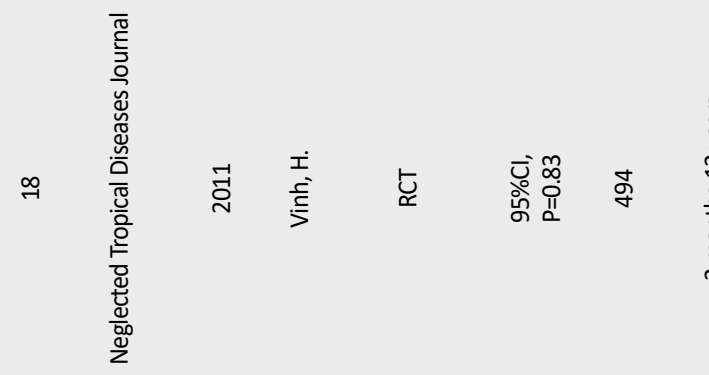

Both ciprofloxacin and gatifloxacin showed similar efficacy in the treatment of dysentery.

No evidence of and

ciprofloxacin-related arthropathy has been identified in this study with a two-year follow-up of ciprofloxacin-treated children.

This study confirms the safety of fluoroquinolones in pediatrics.

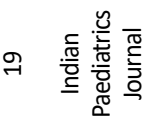
윰

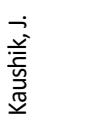

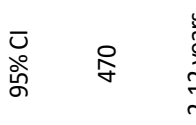

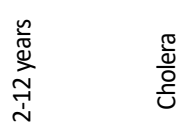

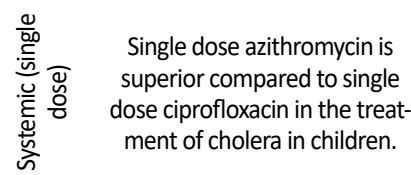

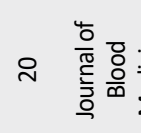

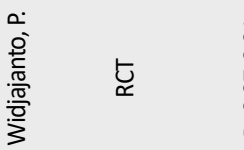

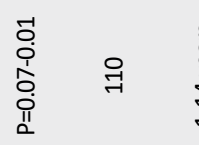

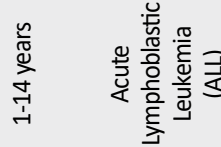

Diarrhea
Nausea
Vomiting
Neuritis

Using ciprofloxacin as prophylaxis during the induction treatment has shown a lower neutrophil count and a higher rate of mortality. 


\begin{tabular}{|c|c|c|c|c|c|c|c|c|c|c|c|}
\hline i & $\begin{array}{l}\bar{\pi} \\
\stackrel{5}{5}\end{array}$ & 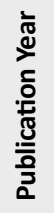 & 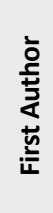 & 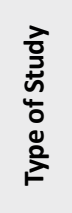 & $\begin{array}{l}\bar{U} \\
\alpha^{\prime}\end{array}$ & $\begin{array}{l}\dot{0} \\
\vdots \\
\vdots \\
0\end{array}$ & 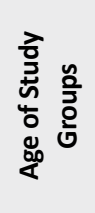 & 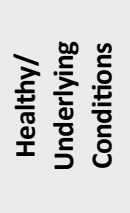 & 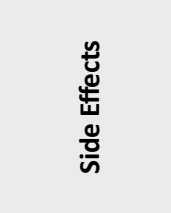 & 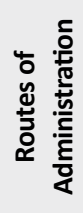 & 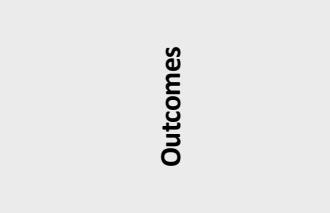 \\
\hline$\vec{N}$ & 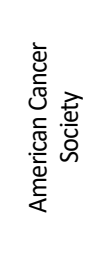 & ষ্ণ & $\begin{array}{l}\text { s. } \\
\text { 言 } \\
\frac{9}{4}\end{array}$ & 七 & ' & $\tilde{m}$ & 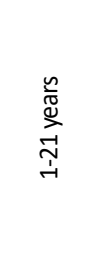 & 离 & $\begin{array}{l}\text { In total, } \\
2 / 45 \text { severe } \\
\text { vomiting and } \\
\text { required hospi- } \\
\text { talization }\end{array}$ & 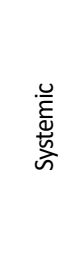 & $\begin{array}{l}\text { A total of } 89 \% \text { of patients } \\
\text { were treated successfully in } \\
\text { outpatient settings with oral } \\
\text { ciprofloxacin for febrile neu- } \\
\text { tropenia. } \\
\text { A study with larger sample size } \\
\text { is required to confirm the safety } \\
\text { of this approach. }\end{array}$ \\
\hline$\approx$ & 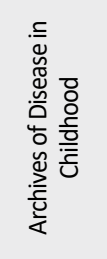 & ஓ̆ & $\begin{array}{l}\dot{0} \\
\overline{\overline{0}} \\
\overline{ \pm} \\
\overline{0}\end{array}$ & 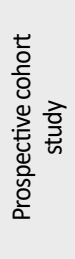 & $\begin{array}{l}\overline{\text { }} \\
\text { ओें }\end{array}$ & $\underset{m}{\mathscr{m}}$ & 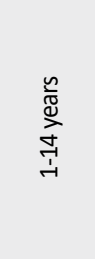 & 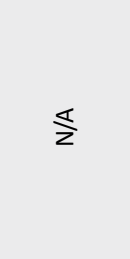 & - & 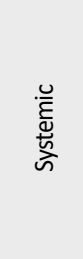 & $\begin{array}{l}\text { No evidence of acute or } \\
\text { subclinical joint toxicity was } \\
\text { observed during the treat- } \\
\text { ment and after two years of } \\
\text { follow-up. } \\
\text { No reason to withhold FQ an- } \\
\text { tibiotics in pediatrics when no } \\
\text { safe alternative was available. }\end{array}$ \\
\hline$\stackrel{\sim}{\sim}$ & 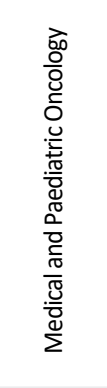 & ষ্ণ & 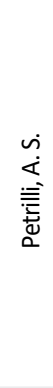 & 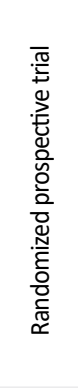 & 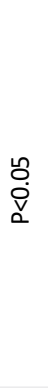 & $\underset{\sim}{\mathscr{\sim}}$ & 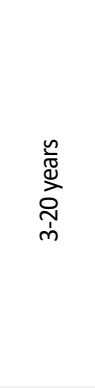 & 离 & $\begin{array}{l}\text { Gl side effects } \\
\text { (nausea, } \\
\text { vomiting, } \\
\text { diarrhea and } \\
\text { epigastric pain) }\end{array}$ & 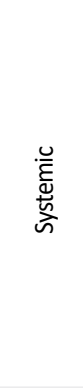 & $\begin{array}{c}\text { In low-risk febrile neutropenia, } \\
\text { patients were treated success- } \\
\text { fully as an outpatient for fever } \\
\text { due to infection. } \\
\text { Both oral ciprofloxacin and } \\
\text { IV ceftriaxone have yielded } \\
\text { therapeutic success. } \\
\text { Treating children in outpatient } \\
\text { settings have a number of ben- } \\
\text { efits, including better patient } \\
\text { satisfaction, low cost, and low } \\
\text { nosocomial infection risk. }\end{array}$ \\
\hline$\stackrel{d}{\sim}$ & 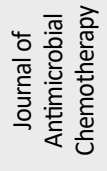 & ริ & 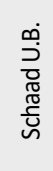 & Ł & ' & $\stackrel{\infty}{\sim}$ & 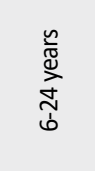 & $\frac{\sqrt{n}}{\stackrel{\frac{11}{5}}{u}}$ & N/A & 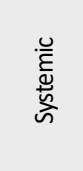 & $\begin{array}{l}\text { No evidence of arthropatho- } \\
\text { genicity was observed during } \\
\text { this comprehensive monitoring. }\end{array}$ \\
\hline$\stackrel{\stackrel{n}{N}}{ }$ & 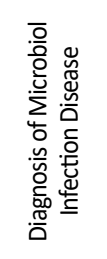 & જ్ & $\begin{array}{l}> \\
\text { خें } \\
\text { हु } \\
\text { 立 }\end{array}$ & 逑 & ' & 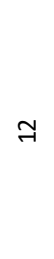 & 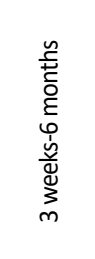 & ' & & 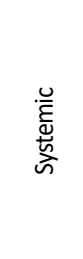 & $\begin{array}{l}\text { Despite the occurrence of } \\
\text { arthropathy in animals, the } \\
\text { ciprofloxacin-induced joint } \\
\text { toxicity in neonates has not } \\
\text { been confirmed. } \\
\text { However, due to the risk, the } \\
\text { duration of the therapy should } \\
\text { be limited. }\end{array}$ \\
\hline
\end{tabular}

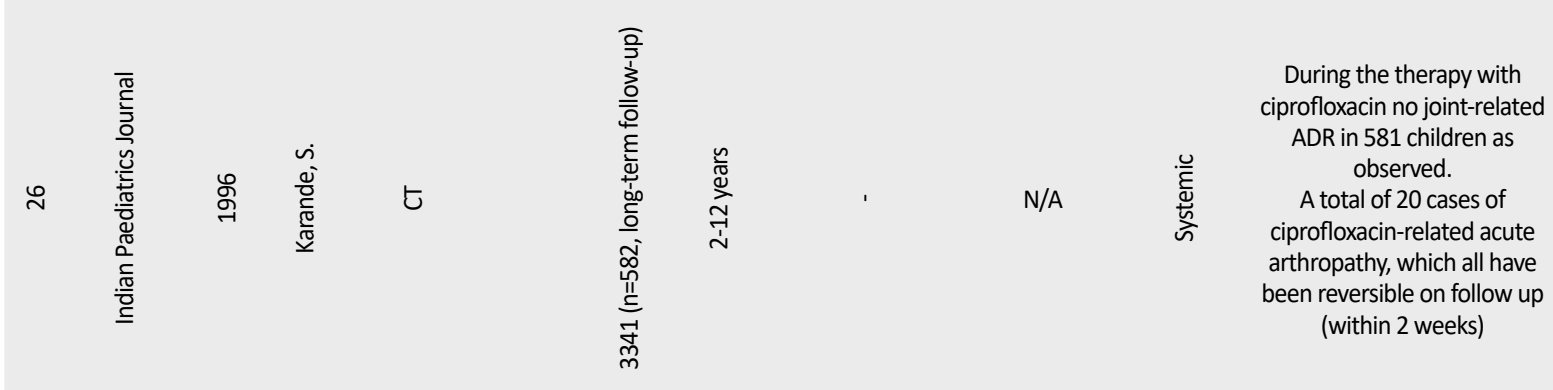

Abbreviations: RCT: Randomized Clinical Trial; CT: Clinical Trial; CF: Cystic Fibrosis; IV: Intravenous

Journal of Pediatrics Review 